\title{
Initiation of the Indosinian Orogeny in South China: Evidence for a Permian Magmatic Arc on Hainan Island
}

\author{
Xian-Hua Li, Zheng-Xiang Li, ${ }^{1}$ Wu-Xian Li, and Yuejun Wang \\ Key Laboratory of Isotope Geochronology and Geochemistry, Guangzhou Institute of Geochemistry, \\ Chinese Academy of Sciences, Guangzhou 510640, China \\ (e-mail: lixh@gig.ac.cn)
}

\begin{abstract}
A B S T R A C T
It has been widely accepted that an active continental margin existed along the coast of Southeast China during the Mesozoic time that produced extensive magmatism in the region. However, there is little constraint as to when this active margin was first initiated. Here we present new SHRIMP U-Pb zircon ages and geochemical and Sr-Nd isotopic data for syntectonic granites on Hainan Island. Our data demonstrate that these rocks, dated at 267-262 Ma, are typical of calc-alkaline I-type granites formed in continental arc environments. The age of this magmatic arc coincides with a sudden change in sedimentary environments in South China during the Permian time, suggesting that the South China Indosinian Orogeny was likely contemporaneous with the onset of continental arc magmatism.
\end{abstract}

Online enhancement: appendix table.

\section{Introduction}

Present-day Southeast Asia comprises a complex assembly of allochthonous continental blocks that amalgamated during the Early Mesozoic after they rifted away from Gondwanaland (Metcalfe 1996). South China was the largest among these blocks and played key roles in the formation of continental Southeast Asia (fig. 1). Extensive studies have been conducted on the Qinling-Dabie Orogen along its northern margin (e.g., Li et al. 1993; Hacker et al. 1998; Meng and Zhang 2000), the Longmenshan fold belt along its northwestern margin (e.g., Chen and Wilson 1996; Roger et al. 2004; Harrowfield and Wilson 2005), and the Indosinian Orogen to the south (e.g., Lepvrier et al. 1997, 2004; Carter et al. 2001). However, the orogen within the South China interior, i.e., the South China Indosinian Orogen in Chinese literature (i.e., Cui and Li 1983), is still poorly understood. This orogenic belt is manifested by a series of thrust, ductile shear zones and granitoid intrusions of mainly Triassic age throughout an area ca. $1300 \mathrm{~km}$ wide and $2000 \mathrm{~km}$ long from 2005.

Manuscript received July 18, 2005; accepted December 13,

${ }^{1}$ Tectonics Special Research Centre, School of Earth and Geographical Sciences, University of Western Australia, Crawley, Western Australia 6009, Australia. the coastal areas to the Xuefengshan mountain range in western Hunan Province (e.g., Li 1998; Chen 1999; Yan et al. 2003; Wang et al. 2005). Hsü et al. (1988) proposed an Alpine-type collisional orogenesis in this region by reinterpretation of the Banxi Group as an early Mesozoic mélange. However, this collision model caused considerable debate (Rodgers 1989; Rowley et al. 1989) and was refuted by many subsequent studies (e.g., Chen et al. 1991; Li and McCulloch 1996). Most researchers believe that the southeastern margin of the South China Block was a passive margin until midMesozoic (e.g., Metcalfe 1996; Li 1998) and that the magmatic belt represents a continental magmatic arc that started from ca. $180 \mathrm{Ma}$ and lasted until ca. $90 \mathrm{Ma}$ (e.g., Jahn et al. 1990; Zhou and Li 2000). If correct, this would imply that the coastal magmatic arc had little to do with the Indosinian Orogeny and the development of the early Mesozoic South China Fold Belt. In this article, we present new SHRIMP U-Pb zircon ages and geochemical and Sr-Nd isotopic data that indicate the presence of a continental magmatic arc in southeastern Hainan Island at ca. 270-260 Ma. We suggest that a continental arc system was developed along the South China continental margin in the late Early 


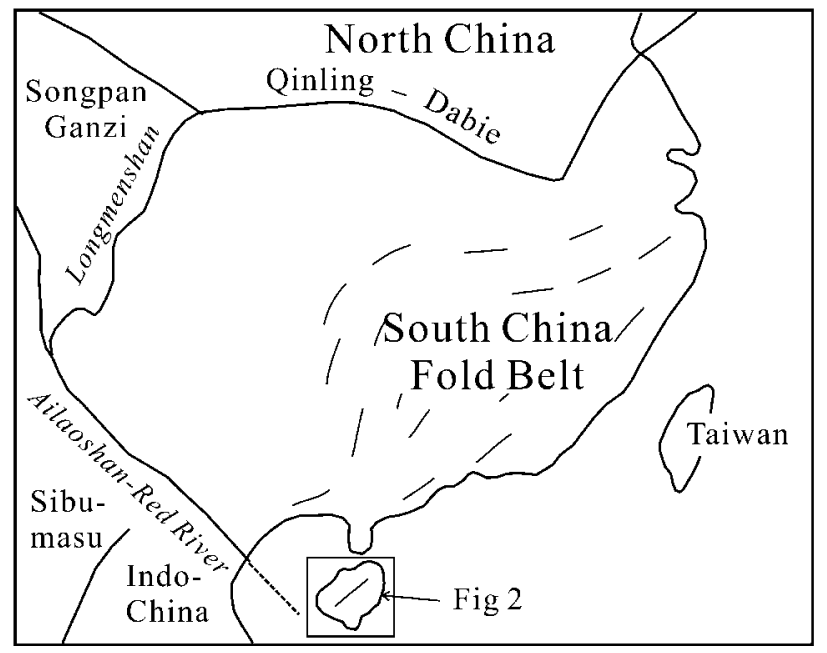

Figure 1. Distributions of principal continental blocks of present-day Southeast Asia and the Indosinian Fold Belt in South China, modified after Metcalfe (1996) and Li (1998).

Permian, which probably signifies the beginning of the Indosinian Orogeny in South China.

\section{Geological Background}

Hainan Island, the second largest island in China, is located off the southern coast of South China. It is a continental-type island separated from the mainland by the Qiongzhou Strait (fig. 2). The Baoban Complex, which was intruded by the $1.43 \mathrm{Ga}$ granitoids (Li et al. 2002b), is known as the oldest basement rock occurring in the southwest part of the island. The island was generally considered part of the Cathaysia block that collided with the Yangtze block by 1000-900 Ma and remained part of that block (e.g., Li et al. 2002b).

Granitoid rocks account for ca. $40 \%$ of the island's land area, with ca. $60 \%$ of them being considered of Indosinian (Triassic) age and the remainder of Yanshanian (Jurassic and Cretaceous) age (Wang et al. 1991). The Indosinian granitoids are mainly nonfoliated, medium- to coarse-grained monzogranite with abundant K-feldspar megacrysts that outcrop mainly in the central part of the island. They are named the Qiongzhong and Danxian batholiths in the southeast and northwest, respectively, separated by the Cretaceous Baisha Basin. Strongly foliated granitoids outcrop over an area of ca. $800 \mathrm{~km}^{2}$ in the Wuzhishan Range within the Qiongzhong batholith (fig. 2). We name them the Wuzhishan Orthogneiss, which was previously misidentified as the "Shang'an migmatite" of un- known age (Wang et al. 1991). The gneissic foliations, defined by parallel-oriented K-feldspar phenocrysts and biotite flakes (fig. 3), have dominant NE to ENE strike directions $\left(30^{\circ}-80^{\circ}\right)$ and dip at medium angles toward the southeast. The Wuzhishan Orthogneiss is composed predominantly of biotite granite and granodiorite, consisting of rockforming minerals of quartz, K-feldspar, plagioclase, biotite, hornblende, and pyroxene as well as accessory minerals including zircon, apatite, allanite, titanite, magnetite, and ilmenite. Mafic magmatic enclaves occur sporadically in the orthogneiss. Some highly felsic granitic samples contain $1 \%-$ $2 \%$ garnet. In the Tongza area, the Wuzhishan Orthogneiss was intruded by the Indosinian Qiongzhong granite, and the orthogneiss occurs as enclaves in sizes from several tens of centimeters up to $10 \mathrm{~m}$ inside the coarse-grained, K-feldspar megacryst-enriched monzogranite (Wang et al. 1991).

\section{Analytical Procedures}

Zircons were separated from two granite samples using standard density and magnetic separation techniques. Zircon grains, together with a zircon $\mathrm{U}-\mathrm{Pb}$ standard (TEMORA), were cast in an epoxy mount, which was then polished to section the crystals in half for analysis. Zircons were documented with transmitted and reflected light micrographs as well as cathodoluminescence $(\mathrm{CL}) \mathrm{im}$ ages to reveal their internal structures, and the mount was vacuum-coated with a 500-nm layer of high-purity gold. Measurements of $\mathrm{U}, \mathrm{Th}$, and $\mathrm{Pb}$ were conducted using a SHRIMP II ion microprobe in the Institute of Geology, Chinese Academy of Geological Sciences (Beijing) for sample 99HN25-4 and the Curtin University of Technology (Perth) for sample 04HN278. U-Th-Pb ratios were determined relative to the TEMORA standard zircon with ${ }^{206} \mathrm{~Pb} /{ }^{238} \mathrm{U}=0.0668$ corresponding to $417 \mathrm{Ma}$ (Black et al. 2003), and the absolute abundances were calibrated to the standard zircons SL13 and CZ3. Analyses of the TEMORA standard zircon were interspersed with those of unknown grains, following operating and data processing procedures similar to those described by Williams (1998). Measured compositions were corrected for common $\mathrm{Pb}$ using the ${ }^{204} \mathrm{~Pb}$ method. Corrections were sufficiently small and insensitive to the choice of common $\mathrm{Pb}$ composition, and an average crustal composition (Cumming and Richards 1975) appropriate to the age of the mineral was assumed. Uncertainties on individual analyses are reported at the $1 \sigma$ level; mean ages for pooled ${ }^{206} \mathrm{~Pb} /{ }^{238} \mathrm{U}$ results are 


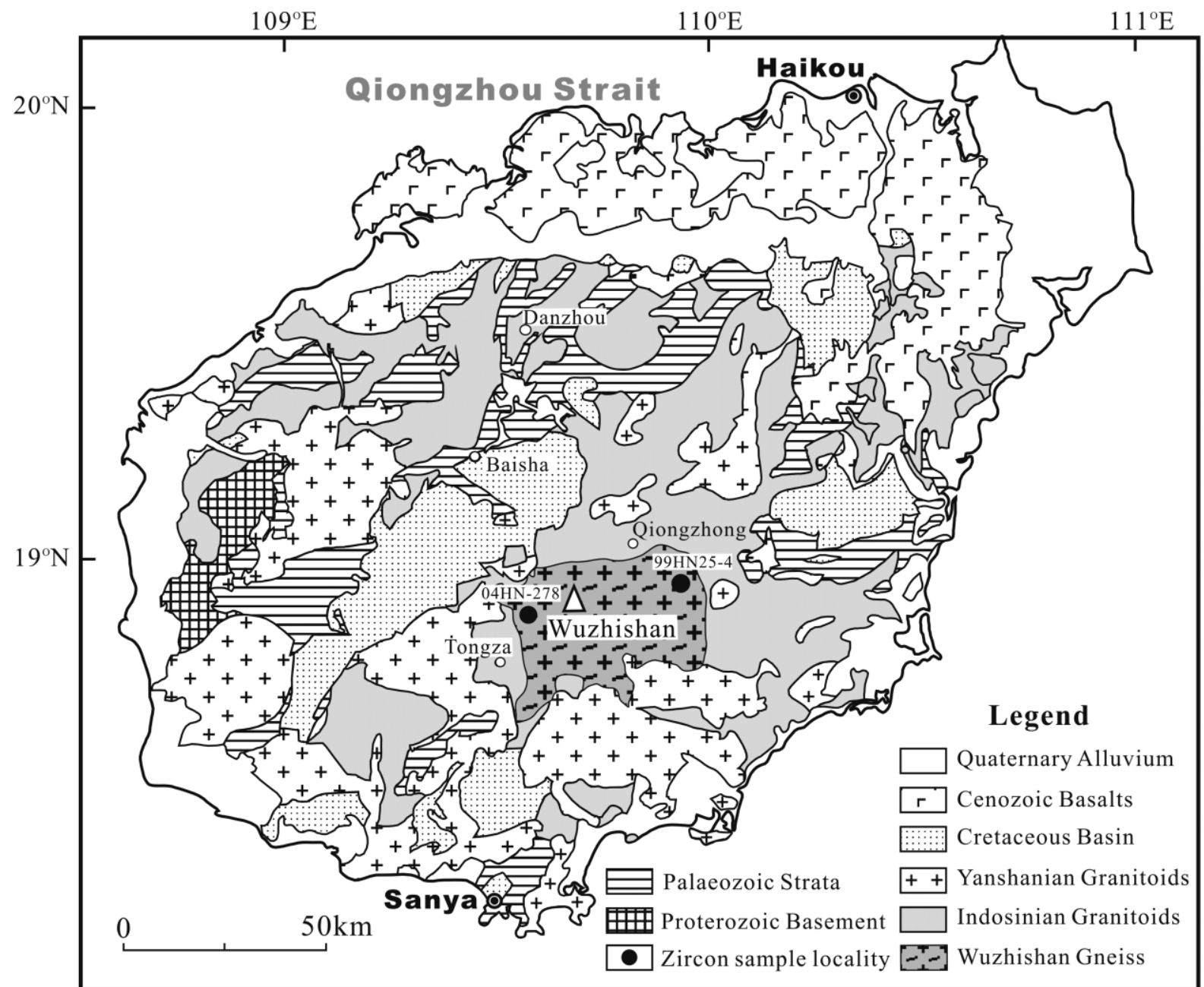

Figure 2. Simplified geological map of Hainan Island, modified after Wang et al. (1991) and Li et al. (2002a).

quoted at the $95 \%$ confidence level. The U-Pb zircon data are presented in table 1.

After petrographic examination, the freshest samples from the Wuzhishan Orthogneiss were selected for geochemical and $\mathrm{Sr}$ and $\mathrm{Nd}$ isotopic analyses at the Guangzhou Institute of Geochemistry, Chinese Academy of Sciences. The geochemical data are presented in table A1 (available in the online edition or from the Journal of Geology office). Major-element oxides were determined by x-ray fluorescence techniques on fused glass beads using a Rigaku ZSX100e spectrometer, and the analytical precision ranges from $1 \%$ to $5 \%$. Trace elements were analyzed using a Perkin-Elmer Sciex ELAN 6000 inductively coupled plasma mass spectrometer (ICP-MS). Analytical procedures are similar to those described by Li (1997). Analytical precision is generally within $5 \%$.
Sr and $\mathrm{Nd}$ isotopic analyses were performed on a Micromass Isoprobe multicollector ICP-MS using analytical procedures described by Wei et al. (2002) and Li et al. (2004). Sr and rare earth elements (REEs) were separated using cation columns, and $\mathrm{Nd}$ fractions were further separated by HDEHPcoated Kef columns. The aqueous $\mathrm{Sr}$ and $\mathrm{Nd}$ solutions were taken up in $2 \% \mathrm{HNO}_{3}$ and introduced into the multicollector ICP-MS using a Meinhard glass nebulizer with an uptake rate of $0.1 \mathrm{~mL} / \mathrm{min}$. Measured ${ }^{87} \mathrm{Sr} /{ }^{86} \mathrm{Sr}$ and ${ }^{143} \mathrm{Nd} /{ }^{144} \mathrm{Nd}$ ratios were normalized to ${ }^{86} \mathrm{Sr} /{ }^{88} \mathrm{Sr}=0.1194$ and ${ }^{146} \mathrm{Nd} /{ }^{144} \mathrm{Nd}=$ 0.7219 , respectively. The reported ${ }^{87} \mathrm{Sr} /{ }^{86} \mathrm{Sr}$ and ${ }^{143} \mathrm{Nd} /{ }^{144} \mathrm{Nd}$ ratios were adjusted, respectively, to the NBS SRM 987 standard ${ }^{87} \mathrm{Sr} /{ }^{86} \mathrm{Sr}=0.71025$ and the Shin Etsu JNdi-1 standard ${ }^{143} \mathrm{Nd} /{ }^{144} \mathrm{Nd}=$ 0.512115 . Sr and $\mathrm{Nd}$ isotopic data are presented in table 2. 


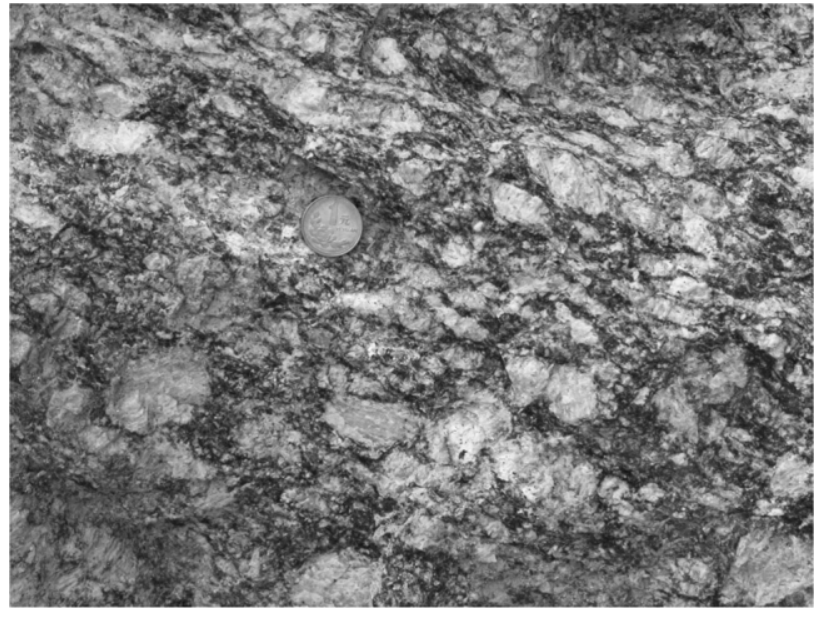

Figure 3. Photograph of the Wuzhishan Orthogneiss.

\section{SHRIMP U-Pb Age Results}

Sample 99HN25-4. This is a medium-grained granite from the eastern part of the Wuzhishan Orthogneiss (18 $\left.54^{\prime} 38^{\prime \prime} \mathrm{N}, 109^{\circ} 58^{\prime} 07^{\prime \prime} \mathrm{E}\right)$. Zircons are mostly euhedral showing concentric zoning, range up to $100-150 \mu \mathrm{m}$ in length, and have length to width ratios of about $2: 1$ to $3: 1$. Most are relatively transparent and colorless, although a few are dark brown and turbid as a result of high uranium content. Euhedral concentric zoning is common in most crystals; inherited zircon cores were rare. Seventeen analyses of 17 zircons were obtained in sets of five scans during a single analytical session (table 1). They have moderately high, variable abundance of Th (86-694 ppm) and U (747-2245 ppm), with the exception of spot 11.1, which has low abundance of Th $(60 \mathrm{ppm})$ and $U(215 \mathrm{ppm})$. Th/U ratios vary between 0.10 and 0.76 , mostly clustering around $0.2-0.3$. Common $\mathrm{Pb}$ is very low; the proportion of common ${ }^{206} \mathrm{~Pb}$ in total measured ${ }^{206} \mathrm{~Pb}$ $\left(f_{206}\right.$ in table 1$)$ is between $0.18 \%$ and $0.87 \%$, except for spot $11.1\left(f_{206}=1.21 \%\right)$. For 16 of 17 analyses, ${ }^{238} \mathrm{U} /{ }^{206} \mathrm{~Pb}$ ratios agree internally to within analytical precision. The best estimate of the crystallization age of sample 99HN25-4, based on the mean ${ }^{206} \mathrm{~Pb} /{ }^{238} \mathrm{U}$ ratio, is $267 \pm 3 \mathrm{Ma}(95 \%$ confidence interval; fig. 4, top). The rejected analysis of spot 11.1 yields a ${ }^{206} \mathrm{~Pb} /{ }^{238} \mathrm{U}$ age of $374 \mathrm{Ma}$, and it is interpreted to be a xenocryst.

Sample 04HN278. This is a coarse-grained granite from the western part of the Wuzhishan orthogneiss (18 $\left.52^{\prime} 51^{\prime \prime} \mathrm{N}, 1^{\circ} 9^{\circ} 36^{\prime} 19^{\prime \prime} \mathrm{E}\right)$. Zircons were mostly euhedral showing concentric zoning, range up to $250 \mu \mathrm{m}$ in length, and have length to width ratios of about $3: 1$. Fourteen analyses of 14 zircons were obtained (table 1). The analyzed zircons have Th (75-559 ppm) and U (334-1440 ppm) concentrations similar to those of sample 99HN254 and fairly homogeneous $\mathrm{Th} / \mathrm{U}$ ratios between 0.19 and 0.40 . Common $\mathrm{Pb}$ is very low, with most spots having $f_{206}=0 \%-0.23 \%$, except for spot 7.1 , which has a significantly high $f_{206}$ value of $0.63 \%$ and a young ${ }^{206} \mathrm{~Pb} /{ }^{238} \mathrm{U}$ age of $170.9 \mathrm{Ma}$ because of subsequent $\mathrm{Pb}$ loss. The remaining 13 analyses have generally consistent ${ }^{206} \mathrm{~Pb} /{ }^{238} \mathrm{U}$ ages between $247.5 \pm 1.4$ and $267.0 \pm 0.8 \mathrm{Ma}(1 \sigma)$, yielding a mean ${ }^{206} \mathrm{~Pb} /{ }^{238} \mathrm{U}$ age of $259 \pm 4 \mathrm{Ma}$. If we consider these 13 analyses, spots 2.1 and 3.1 show clear deviation in ${ }^{206} \mathrm{~Pb} /{ }^{238} \mathrm{U}$ age from the main population possibly because of slight $\mathrm{Pb}$ loss. If we reject these two analyses, the other 11 analyses have indistinguishable ${ }^{238} \mathrm{U} /{ }^{206} \mathrm{~Pb}$ ratios within analytical precision, corresponding to a single-age population with a weighted mean ${ }^{206} \mathrm{~Pb} /{ }^{238} \mathrm{U}$ age of $262 \pm 3 \mathrm{Ma}$ (fig. 4 , bottom), which is interpreted as the best estimate of the crystallization age of sample 04HN278.

\section{Geochemistry}

The Wuzhishan Orthogneiss rocks have a wide range of chemical composition, with $\mathrm{SiO}_{2}=$ $60.8 \%-74.5 \%, \quad \mathrm{Al}_{2} \mathrm{O}_{3}=16.3 \%-12.6 \%, \quad \mathrm{MgO}=$ $2.3 \%-0.3 \%, \quad \mathrm{Fe}_{2} \mathrm{O}_{3}=6.8 \%-1.7 \%$, and $\mathrm{CaO}=$ $5.0 \%-1.0 \%$ (table A1). They have relatively high contents of alkalis, with $\mathrm{K}_{2} \mathrm{O}=2.3 \%-6.9 \%$ and $\mathrm{Na}_{2} \mathrm{O}=2.4 \%-3.2 \%$, and the total $\mathrm{K}_{2} \mathrm{O}+\mathrm{Na}_{2} \mathrm{O}$ varies from $6.3 \%$ to $9.4 \% . \mathrm{Al}_{2} \mathrm{O}_{3}, \mathrm{Fe}_{2} \mathrm{O}_{3}, \mathrm{TiO}_{2}, \mathrm{MgO}$, $\mathrm{CaO}, \mathrm{P}_{2} \mathrm{O}_{5}, \mathrm{MnO}, \mathrm{Sr}$, and $\mathrm{Ba}$ decrease with increasing $\mathrm{SiO}_{2}$, whereas $\mathrm{Na}_{2} \mathrm{O}$ remains nearly constant (fig. 5). These chemical variations are consistent with the crystal fractionation of ferromagnesian minerals, plagioclase, Ti-Fe oxides, and apatite. On a K-Na-Ca diagram (fig. 6), the Wuzhishan rocks plot near the calc-alkaline trend defined by Barker and Arth (1976). Their A/CNK values range from 0.90 to $1.08 \quad(\mathrm{~A} / \mathrm{CNK}=$ molar ratio of $\left.\mathrm{Al}_{2} \mathrm{O}_{3} /\left[\mathrm{CaO}+\mathrm{K}_{2} \mathrm{O}+\mathrm{Na}_{2} \mathrm{O}\right]\right)$, transitional from metaluminous to weak peraluminous (fig. $7 a$ ), and increase with increasing $\mathrm{SiO}_{2}$ (fig. $7 b$ ), similar to the trend of fractionation of hornblende, biotite, and plagioclase from a calc-alkaline magma moving the metaluminous liquid toward the peraluminous field.

The Wuzhishan rocks have generally similar REE patterns (fig. 8a) showing variable enrichment of light rare earth elements (LREEs), with chondritenormalized $\mathrm{La}_{\mathrm{N}}=82-565$ and $\mathrm{La}_{\mathrm{N}} / \mathrm{Yb}_{\mathrm{N}}=5-125$. Negative Eu anomaly is moderate to significant for most samples, with $\mathrm{Eu}^{*} / \mathrm{Eu}=0.66-0.18$, apart from the least felsic sample, 04HN207, which lacks a 
Table 1. SHRIMP U-Pb Zircon Data

\begin{tabular}{|c|c|c|c|c|c|c|c|}
\hline Spot & $\begin{array}{c}\mathrm{U} \\
(\mathrm{ppm})\end{array}$ & $\begin{array}{c}\mathrm{Th} \\
\text { (ppm) }\end{array}$ & $\mathrm{Th} / \mathrm{U}$ & $\begin{array}{l}f_{206}{ }^{a} \\
(\%) \\
\end{array}$ & $\begin{array}{c}{ }^{207} \mathrm{~Pb}^{*} /{ }^{235} \mathrm{U} \\
( \pm 1 \sigma)\end{array}$ & $\begin{array}{c}{ }^{206} \mathrm{~Pb}^{*} /{ }^{238} \mathrm{U} \\
( \pm 1 \sigma)\end{array}$ & $\begin{array}{c}{ }^{206} \mathrm{~Pb} /{ }^{238} \mathrm{U} \text { age } \\
(\mathrm{Ma} ; \pm 1 \sigma)\end{array}$ \\
\hline \multicolumn{8}{|c|}{ 99HN25-4 (18 $\left.54^{\prime} 38^{\prime \prime} \mathrm{N}, 109^{\circ} 58^{\prime} 07^{\prime \prime} \mathrm{E}\right):$} \\
\hline 1.1 & 795 & 88 & .11 & .55 & $.300(.009)$ & $.0421(.0009)$ & $265.9(5.5)$ \\
\hline 2.1 & 854 & 86 & .10 & .73 & $.290(.008)$ & $.0413(.0008)$ & $260.6(5.3)$ \\
\hline 3.1 & 2275 & 353 & .16 & .28 & $.305(.007)$ & $.0423(.0008)$ & $267.3(5.4)$ \\
\hline 4.1 & 1268 & 256 & .21 & .39 & $.309(.008)$ & $.0416(.0008)$ & $262.6(5.4)$ \\
\hline 5.1 & 1084 & 316 & .30 & .54 & $.311(.009)$ & $.0431(.0009)$ & $272.3(5.7)$ \\
\hline 6.1 & 747 & 137 & .19 & .87 & $.313(.010)$ & $.0434(.0009)$ & $273.6(5.7)$ \\
\hline 7.1 & 1375 & 260 & .20 & .44 & .307 (.009) & $.0430(.0009)$ & $271.6(5.6)$ \\
\hline 8.1 & 1839 & 609 & .34 & .18 & $.300(.007)$ & $.0410(.0008)$ & $259.0(5.4)$ \\
\hline 9.1 & 940 & 694 & .76 & .78 & $.295(.012)$ & $.0431(.0009)$ & $271.9(6.2)$ \\
\hline 10.1 & 1662 & 366 & .23 & .42 & $.290(.007)$ & $.0412(.0008)$ & $260.0(5.3)$ \\
\hline 11.1 & 215 & 60 & .29 & 1.21 & $.475(.017)$ & $.0597(.0013)$ & $374.0(8.5)$ \\
\hline 12.1 & 1060 & 237 & .23 & .52 & $.295(.008)$ & $.0416(.0008)$ & $262.8(5.4)$ \\
\hline 13.1 & 1197 & 253 & .22 & .49 & $.309(.008)$ & $.0436(.0009)$ & $274.9(5.7)$ \\
\hline 14.1 & 1740 & 347 & .21 & .51 & .303 (.009) & $.0431(.0009)$ & $272.0(5.6)$ \\
\hline 15.1 & 1431 & 269 & .19 & .44 & $.302(.007)$ & $.0425(.0009)$ & $268.0(5.5)$ \\
\hline 16.1 & 1543 & 334 & .22 & .66 & $300(.009)$ & $.0419(.0010)$ & $264.9(6.2)$ \\
\hline 17.1 & 779 & 191 & .25 & .83 & $.298(.011)$ & $.0421(.0011)$ & $266.0(6.8)$ \\
\hline Weighted mean ${ }^{\mathrm{b}}$ & & & & & & & $266.9(2.8)$ \\
\hline \multicolumn{8}{|c|}{ 04HN278 (18 $\left.52^{\prime} 51^{\prime \prime} \mathrm{N}, 109^{\circ} 36^{\prime} 19^{\prime \prime} \mathrm{E}\right):$} \\
\hline 1.1 & 447 & 166 & .38 & .00 & $.301(.007)$ & $.0413(.0002)$ & $260.6(1.4)$ \\
\hline 2.1 & 611 & 139 & .23 & .10 & $.276(.007)$ & $.0394(.0002)$ & $248.9(1.1)$ \\
\hline 3.1 & 440 & 91 & .21 & .23 & $.270(.010)$ & $.0391(.0002)$ & $247.5(1.4)$ \\
\hline 4.1 & 607 & 162 & .28 & .00 & $.287(.006)$ & $.0402(.0002)$ & $253.8(1.1)$ \\
\hline 5.1 & 376 & 89 & .24 & .08 & $.295(.011)$ & $.0414(.0002)$ & $261.5(1.5)$ \\
\hline 6.1 & 397 & 129 & .34 & .17 & $.283(.009)$ & $.0408(.0002)$ & $257.5(1.4)$ \\
\hline 7.1 & 425 & 78 & .19 & .63 & $.178(.012)$ & $.0269(.0002)$ & $170.9(1.3)$ \\
\hline 8.1 & 334 & 75 & .23 & .00 & $.304(.009)$ & $.0418(.0004)$ & $264.2(2.4)$ \\
\hline 9.1 & 755 & 202 & .28 & .00 & $.303(.005)$ & $.0414(.0002)$ & $261.8(1.0)$ \\
\hline 10.1 & 1440 & 559 & .40 & .12 & $.299(.004)$ & $.0423(.0001)$ & $267.0(.8)$ \\
\hline 11.1 & 358 & 89 & .26 & .15 & $.300(.011)$ & $.0417(.0003)$ & $263.1(1.8)$ \\
\hline 12.1 & 414 & 109 & .27 & .06 & $.283(.008)$ & $.0403(.0002)$ & $254.5(1.4)$ \\
\hline 13.1 & 665 & 179 & .28 & .00 & $.299(.007)$ & $.0420(.0002)$ & $265.1(1.1)$ \\
\hline 14.1 & 439 & 101 & .24 & .22 & $.282(.008)$ & $.0412(.0002)$ & $260.3(1.4)$ \\
\hline Weighted mean ${ }^{c}$ & & & & & & & $261.6(3.1)$ \\
\hline
\end{tabular}

${ }^{\mathrm{a}} f_{206}$ denotes the proportion of common ${ }^{206} \mathrm{~Pb}$ in total measured ${ }^{206} \mathrm{~Pb}$.

b $95 \%$ confidence interval, $n=16$.

c $95 \%$ confidence interval, $n=11$.

visible Eu anomaly $\left(\mathrm{Eu}^{*} / \mathrm{Eu}=0.93\right)$. A few samples, such as $04 \mathrm{HN} 217$ and $04 \mathrm{HN} 233$, display elevated HREE patterns as a result of the presence of minor amounts of garnet crystals. On the primitive mantle-normalized incompatible element spidergram (fig. 8b), all samples except 04HN207 exhibit significant negative anomalies of $\mathrm{Ba}, \mathrm{Nb}, \mathrm{Sr}$, and $\mathrm{P}$ and positive anomalies of $\mathrm{Rb}, \mathrm{Th}$, and $\mathrm{K}$.

\section{Sr-Nd Isotopes}

Eleven Wuzhishan samples were analyzed for Sr$\mathrm{Nd}$ isotopes (table 2). They have measured ${ }^{87} \mathrm{Rb} /{ }^{86} \mathrm{Sr}=1.39-6.70$ and ${ }^{87} \mathrm{Sr} /{ }^{86} \mathrm{Sr}=0.71363-$ 0.73406 , and the calculated initial $I_{\mathrm{Sr}}=0.7074$ 0.7105 . Their measured ${ }^{147} \mathrm{Sm} /{ }^{144} \mathrm{Nd}=0.0838$ 0.1334 , their measured ${ }^{143} \mathrm{Nd} /{ }^{144} \mathrm{Nd}=0.51212$
0.51232 , and the calculated $\varepsilon \mathrm{Nd}(T)=-3.07$ to -7.72 . There is a negative correlation between $I_{\mathrm{Sr}}$ and $\varepsilon \mathrm{Nd}(T)$ values (fig. 9), suggesting the involvement of two major components in their origin.

The Nd model age $\left(T_{\mathrm{DM}}\right)$ ranges from 1.09 to 1.83 $\mathrm{Ga}$. It is noted, however, that the analyzed samples exhibit significant $\mathrm{Sm} / \mathrm{Nd}$ fractionation that affects the single-stage $T_{\mathrm{DM}}$ age to varying degrees. To minimize this effect, a two-stage $\mathrm{Nd}$ model age $\left(T_{2 \mathrm{DM}}\right)$ is calculated using the same assumption formulation as Keto and Jacobsen (1987):

$$
T_{2 \mathrm{DM}}=T_{\mathrm{DM}}-\left(T_{\mathrm{DM}}-t\right) \times \frac{\left(f_{\mathrm{cc}}-f_{\mathrm{s}}\right)}{\left(f_{\mathrm{cc}}-f_{\mathrm{DM}}\right)^{\prime}}
$$

where $f_{\mathrm{cc}}, f_{\mathrm{DM}}$, and $f_{\mathrm{s}}$ are the $f_{\mathrm{Sm} / \mathrm{Nd}}$ values of the average continental crust $\left(f_{\mathrm{cc}}=-0.4\right)$, the depleted 
Table 2. Sr and Nd Isotopic Data

\begin{tabular}{|c|c|c|c|c|c|c|c|c|}
\hline Sample & ${ }^{87} \mathrm{Rb} /{ }^{86} \mathrm{Sr}^{*}$ & $\begin{array}{c}{ }^{87} \mathrm{Sr} /{ }^{86} \mathrm{Sr} \\
\left( \pm 2 \sigma_{\mathrm{m}}\right)\end{array}$ & $I_{\mathrm{Sr}}$ & ${ }^{147} \mathrm{Sm} /{ }^{144} \mathrm{Nd}^{*}$ & $\begin{array}{c}{ }^{143} \mathrm{Nd} /{ }^{144} \mathrm{Nd} \\
\left( \pm 2 \sigma_{\mathrm{m}}\right)\end{array}$ & $\varepsilon \mathrm{Nd}(T)$ & $\begin{array}{l}T_{\mathrm{DM}} \\
(\mathrm{Ga}) \\
\end{array}$ & $\begin{array}{l}T_{2 \mathrm{DM}} \\
(\mathrm{Ga})\end{array}$ \\
\hline $97 \mathrm{HN} 114$ & 4.36 & $.724852(.000013)$ & .7083 & .090 & $.512244(.000014)$ & -4.03 & 1.11 & 1.37 \\
\hline $04 \mathrm{HN} 214$ & 2.18 & .716608 (.000017) & .7083 & .084 & $.512127(.000013)$ & -6.13 & 1.20 & 1.54 \\
\hline $04 \mathrm{HN} 216$ & 6.02 & $.733385(.000018)$ & .7105 & .128 & $.512123(.000012)$ & -7.72 & 1.83 & 1.66 \\
\hline $04 \mathrm{HN} 223$ & 3.87 & .723503 (.000019) & .7088 & .107 & $.512170(.000012)$ & -6.08 & 1.40 & 1.53 \\
\hline $04 \mathrm{HN} 227$ & 1.63 & $.713632(.000017)$ & .7075 & .085 & $.512235(.000012)$ & -4.07 & 1.09 & 1.37 \\
\hline 04HN231 & 3.91 & $.724865(.000017)$ & .7100 & .105 & $.512178(.000012)$ & -5.85 & 1.36 & 1.51 \\
\hline $04 \mathrm{HN} 233$ & 6.70 & $.734060(.000017)$ & .7086 & .129 & $.512227(.000013)$ & -5.71 & 1.66 & 1.5 \\
\hline $04 \mathrm{HN} 277$ & 1.72 & $.714750(.000017)$ & .7082 & .108 & $.512320(.000013)$ & -3.17 & 1.20 & 1.30 \\
\hline 04HN278 & 1.81 & $.713997(.000017)$ & .7071 & .104 & $.512320(.000012)$ & -3.07 & 1.16 & 1.29 \\
\hline $04 \mathrm{HN} 280$ & 1.67 & $.714371(.000019)$ & .7080 & .106 & $.512279(.000012)$ & -3.90 & 1.23 & 1.36 \\
\hline $99 \mathrm{HN} 25-4$ & 1.25 & $.714033(.000016)$ & .7093 & .133 & $.512285(.000013)$ & -4.73 & 1.64 & 1.42 \\
\hline
\end{tabular}

Note. $\quad{ }^{87} \mathrm{Rb} /{ }^{86} \mathrm{Sr}$ and ${ }^{147} \mathrm{Sm} /{ }^{144} \mathrm{Nd}$ ratios are calculated using the measured contents of $\mathrm{Rb}, \mathrm{Sr}, \mathrm{Sm}$, and Nd by ICP-MS, with internal precision better than $2 \% . T=265 \mathrm{Ma}$, the crystallization age of the Wuzhishan Orthogneiss.

mantle $\left(f_{\mathrm{DM}}=0.08592\right)$, and the measured sample, respectively, and $t$ is the formation age of the granite. It is noteworthy that the assumption of a uniform $\mathrm{Sm} / \mathrm{Nd}$ ratio equal to that of the average continental crust for the protoliths of all granites may not be true. The $T_{2 \mathrm{DM}}$ model ages of Wuzhishan rocks are restricted to the Mesoproterozoic, ranging from 1.29 to $1.54 \mathrm{Ga}$.

\section{Petrogenesis}

The less felsic rocks in the Wuzhishan Orthogneiss are typical of calc-alkaline I-type granites, as indicated by their metaluminous nature and the presence of hornblende. The highly felsic $\left(>72 \% \mathrm{SiO}_{2}\right)$, hornblende-free samples, on the other hand, are peraluminous and high in total alkaline and $\mathrm{FeO}^{*} / \mathrm{MgO}$. They are considered as the fractionated I-type, rather than S- and A-type, granites, formed by extensive fractionation of plagioclase, hornblende, and biotite from the calc-alkaline magma. Evidence for such an interpretation includes the following: (1) their A/CNK value does not exceed 1.1 , in contrast to those highly felsic S-type granites that are usually strongly peraluminous with A/ CNK values $>1.1$ (Chappell 1999); (2) these rocks show a marked decrease in $\mathrm{P}_{2} \mathrm{O}_{5}$ when the silica contents are high (fig. 5), a diagnostic feature of Itype granites when apatite reaches saturation in less peraluminous magmas (Chappell 1999); and (3) the relatively low contents of $\mathrm{Zr}, \mathrm{Nb}, \mathrm{Y}$, LREEs, and $\mathrm{Ga}$, low $10,000 \times \mathrm{Ga} / \mathrm{Al}(<2.7)$, and high $\mathrm{FeO}^{*} / \mathrm{MgO}(4-8)$ are suggestive of fractionated Itype rather than A-type granites (Whalen et al. 1987). A few Wuzhishan rocks contain minor amounts of garnet, which is normally absent from I-type granites but common in S-type granites. This was likely caused by mixing with peraluminous crustal melts (discussed in detail below).
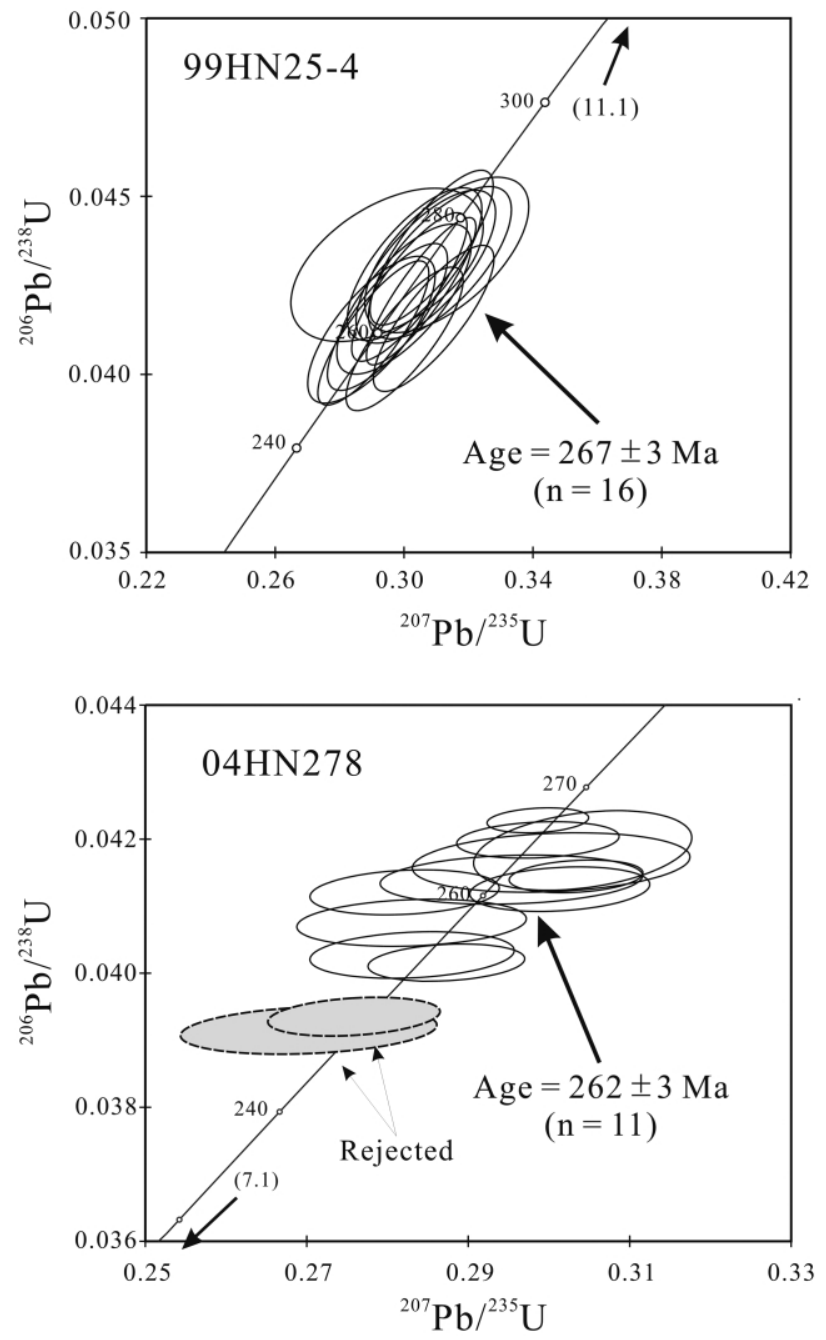

Figure 4. U-Pb zircon concordia diagram for the $\mathrm{Wu}-$ zhishan Orthogneiss. 

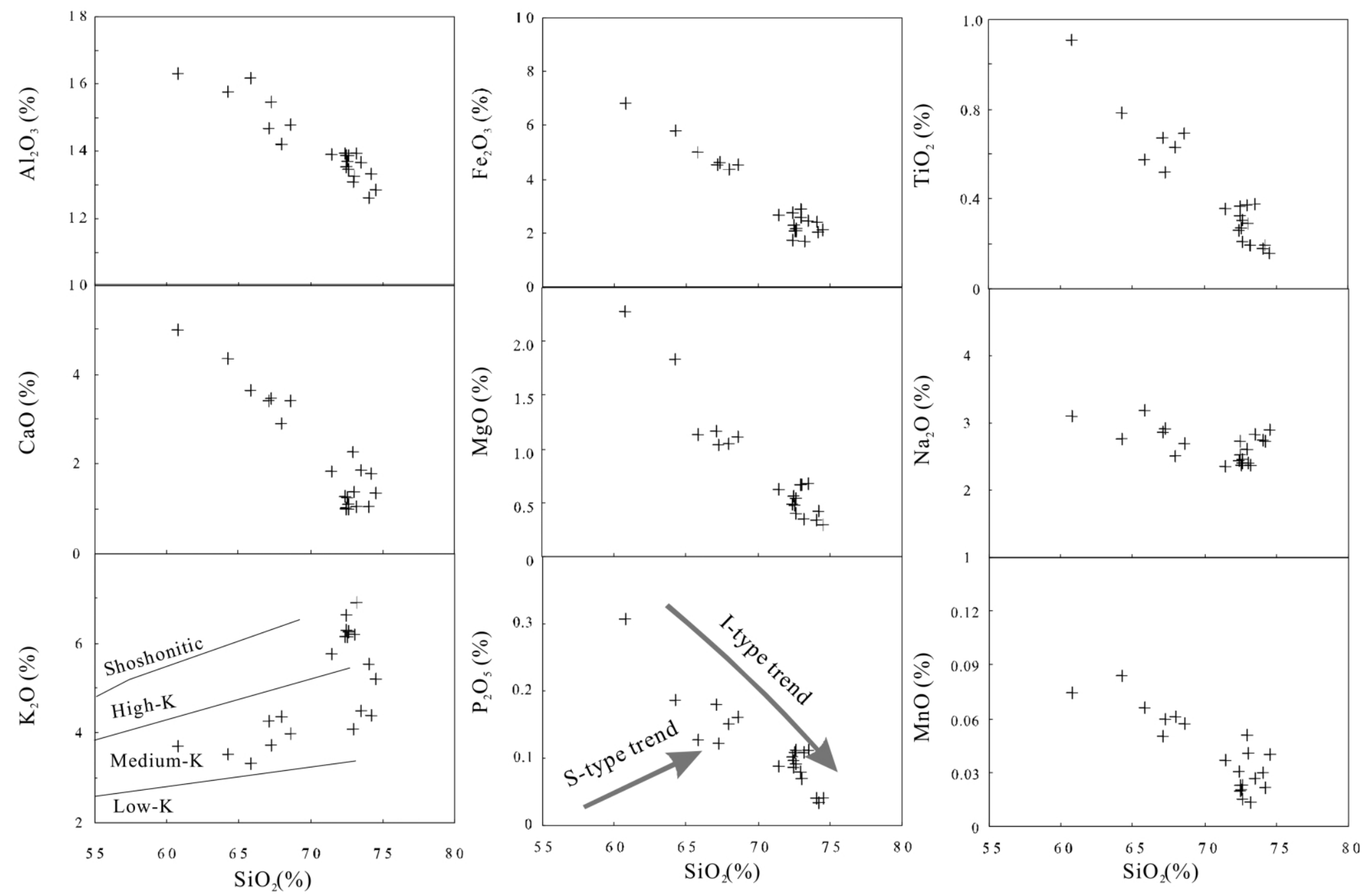

Figure 5. Chemical variation diagrams for the Wuzhishan Orthogneiss samples. 


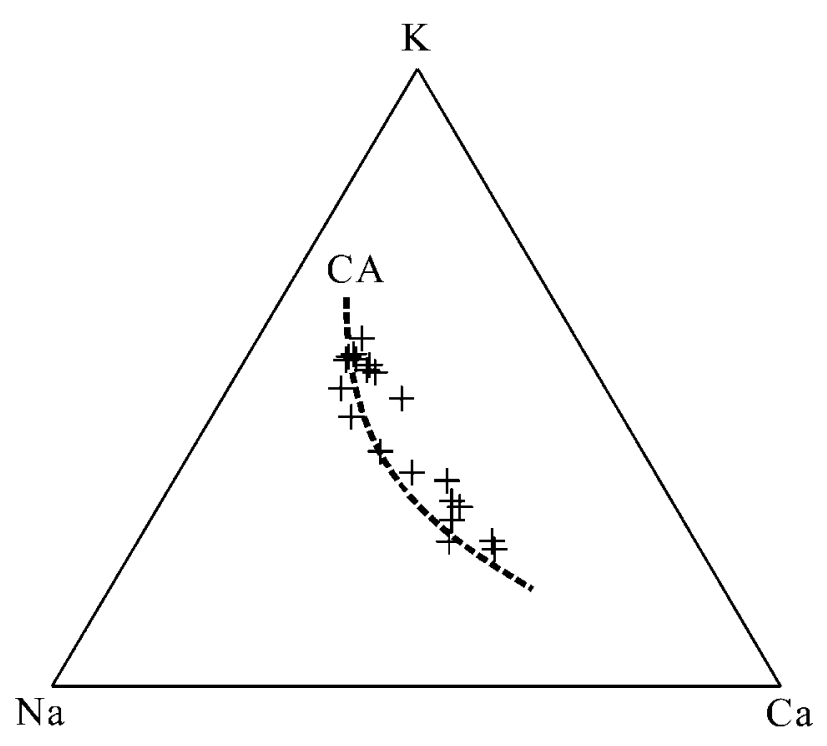

Figure 6. K-Na-Ga triangular plot of Barker and Arth (1976) showing the Wuzhishan Orthogneiss samples that follow the calc-alkaline (CA) trend.

Calc-alkaline, I-type granitoids of intermediate to felsic chemistry are usually generated by lowdegree partial melting or by advanced assimilation fractional crystallization of mantle-derived basaltic sources. Experimental studies indicate that dehydration melting of basaltic amphibolites may produce melts of intermediate to silicic compositions, leaving behind a granulite residue at $8-12 \mathrm{kbar}$ and garnet granulite to eclogite residues at 12-32 kbar (see, e.g., Rushmer 1991; Rapp and Watson 1995). These resultant melts are usually low in $\mathrm{K}_{2} \mathrm{O}$ and high in $\mathrm{Na}_{2} \mathrm{O} / \mathrm{K}_{2} \mathrm{O}$. Using medium- to high-K basaltic compositions as starting materials, K-rich melts $\left(\mathrm{Na}_{2} \mathrm{O} / \mathrm{K}_{2} \mathrm{O}<1\right)$ can be produced for those high-silica melts, but those intermediate melts with $\mathrm{SiO}_{2}<65 \%$ still have $\mathrm{Na}_{2} \mathrm{O} / \mathrm{K}_{2} \mathrm{O}>1$ (Sisson et al. 2005).

All the Wuzhishan rocks are exclusively medium to high $\mathrm{K}$ with $\mathrm{Na}_{2} \mathrm{O} / \mathrm{K}_{2} \mathrm{O}<1$; thus, partial melting of basaltic protoliths is not favored for their origin. The least felsic sample (04HN207) has chemical compositions very similar to those of arc andesites in the Andes at comparable $\mathrm{SiO}_{2}$ levels (HickeyVargas et al. 1989). In the primitive-mantlenormalized spidergram (fig. $8 b$ ), it is characterized by significant negative anomalies of $\mathrm{Nb}, \mathrm{P}, \mathrm{Ti}$, and, to a lesser extent, $\mathrm{Sr}$, resembling the normal arc rock, rather than adakite, which is distinguished by the pronounced positive $\mathrm{Sr}$ anomaly, low abundance of HREE, and high $\mathrm{Sr} / \mathrm{Y}$ and $\mathrm{La} / \mathrm{Yb}$ ratios (Defant et al. 1992). Thus, the Wuzhishan intermediate rocks might have a petrogenetic process similar to that of continental arc andesites that were generated through fractional crystallization of basaltic magma originated from a metasomatized mantle wedge above a subduction zone (Tatsumi and Eggins 1995). This is supported by their Nd-Sr isotopic compositions, which fall into the range of continental arc basalts (fig. 9). Advanced fractionation of plagioclase, hornblende, and biotite resulted in the more felsic rocks.
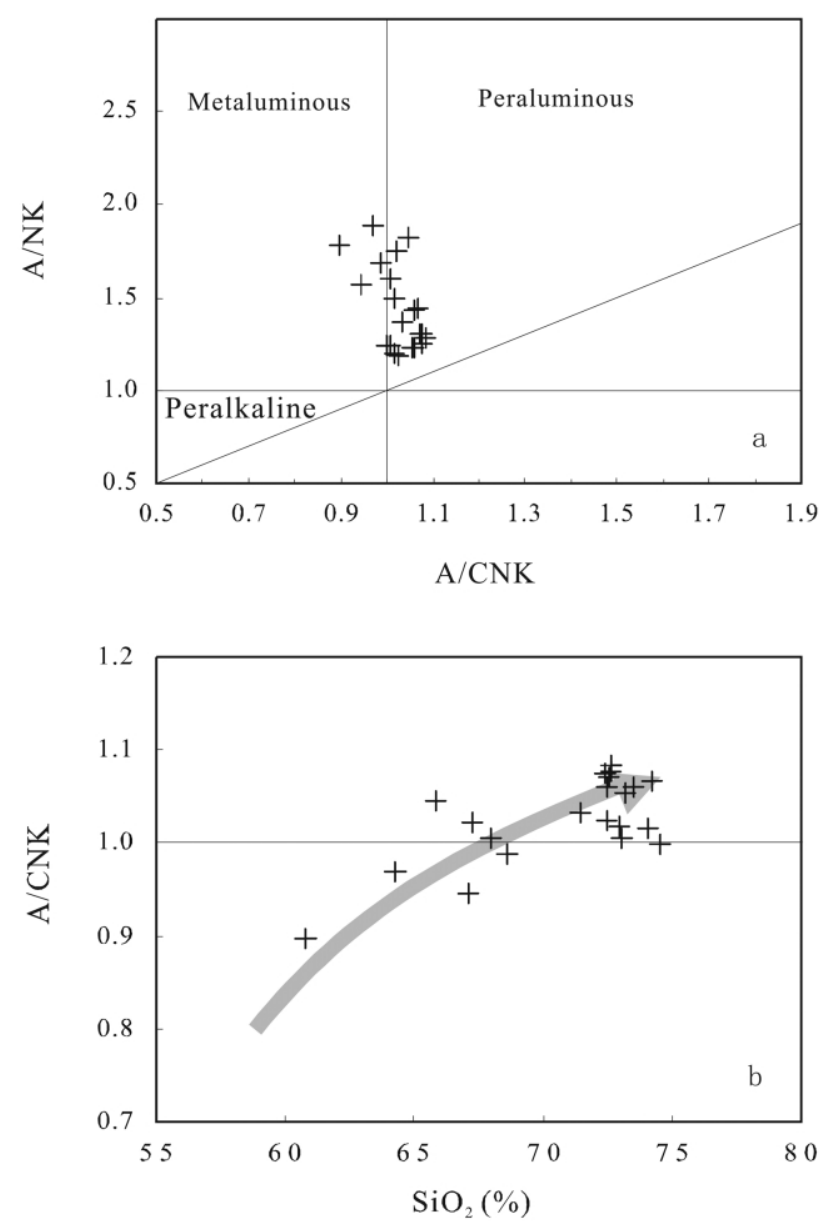

Figure 7. $a, \mathrm{~A} / \mathrm{NK}$ versus A/CNK plot (Maniar and Piccoli 1989) showing the metaluminous to weakly peraluminous nature of the Wuzhishan Orthogneiss rocks. $\mathrm{A}=\mathrm{Al}_{2} \mathrm{O}_{3}, \mathrm{~N}=\mathrm{Na}_{2} \mathrm{O}, \mathrm{K}=\mathrm{K}_{2} \mathrm{O}, \mathrm{C}=\mathrm{CaO}$ (all in molar proportion). $b, \mathrm{~A} / \mathrm{CNK}$ versus $\mathrm{SiO}_{2}$ diagram. A/CNK values increase with increasing $\mathrm{SiO}_{2}$ as a result of extensive fractionation of plagioclase, hornblende, and biotite from a calc-alkaline magma moving the metaluminous liquid toward peraluminous, with the arrowhead representing the maximum degree of calc-alkaline fractionation (after Jahn et al. 2001). 

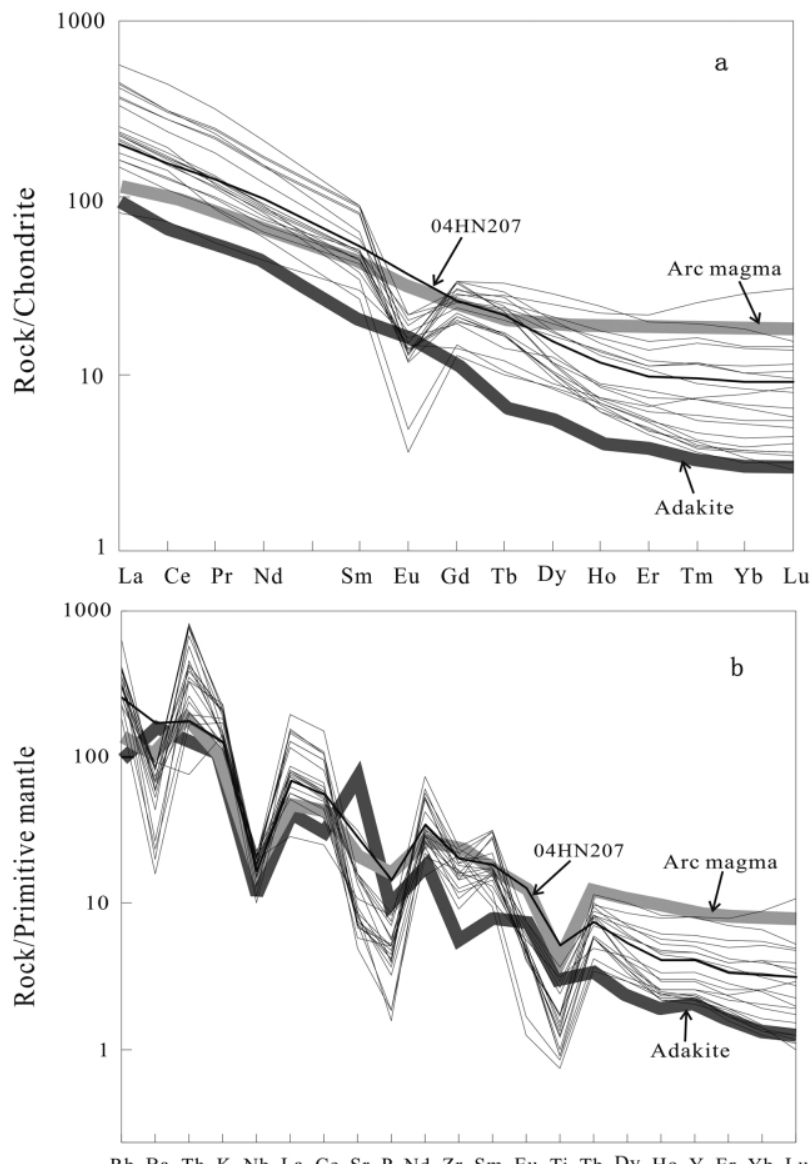

Figure 8. (a) Chondrite-normalized REE patterns and (b) primitive-mantle-normalized incompatible-element spidergrams for the Wuzhishan Orthogneiss. The normalization values are from Sun and McDonough (1989). Average andesite and adakite compositions are from Hickey-Vargas et al. (1989) and Defant et al. (1992).

We note that some highly felsic rocks have very high $\mathrm{K}_{2} \mathrm{O}$ content (exceeding $6 \%$ ) that could not have been generated solely by fractional crystallization. Negative correlations of $\mathrm{SiO}_{2}$ and $\mathrm{K}_{2} \mathrm{O}$ versus $\varepsilon \mathrm{Nd}(T)$ value (fig. 10) clearly argue for the involvement of crust-derived melts in the granitic petrogenesis, although quantitative modeling is hampered by a lack of systematic geochemical and isotopic data for the coeval mantle-derived mafic rocks and the regional crustal components. Mixing of mantle-derived, fractionated mafic to intermediate magma and crustal melts has been considered the major petrogenetic process producing the calcalkaline rock suite typical of continental arcs, such as the western U.S. Cordillera magmatic arc (Barth et al. 1995). In general, the Wuzhishan granitic rocks show close affinities to the I-type granites formed in continental margin arcs.

\section{Tectonic Implications}

The concept of the Indosinian Orogeny was originally defined by the unconformable Upper Triassic red beds overlying the deformed Middle Triassic and older metamorphic rocks in northern Vietnam (Deprat 1914; Lacassin et al. 1998). This orogeny was attributed to the eastward subduction of the Paleo-Tethys ocean plate and collision between the Sibumasu and Indochina blocks. The timing of the subduction and collision is generally regarded as in the range of Late Permian to Early Triassic, with ductile deformation and high-temperature metamorphism clustering around 250-240 Ma (e.g., Lepvrier et al. 1997, 2004; Carter et al. 2001). The Indosinian structures in Vietnam strike mainly E-W to NW-SE (Lepvrier et al. 2004).

Our new SHRIMP U-Pb zircon age results indicate that the arc magmatism on Hainan Island took place in the late Early Permian (ca. 270-260 Ma). The gneissic foliation of the Wuzhishan Orthogneiss dips to the southeast; its orientation is consistent with the generally NE- to ENE-trending structures in the Paleozoic successions in Hainan Island and the Southeast China continent (fig. 1). The timing of magmatic arc and the structure

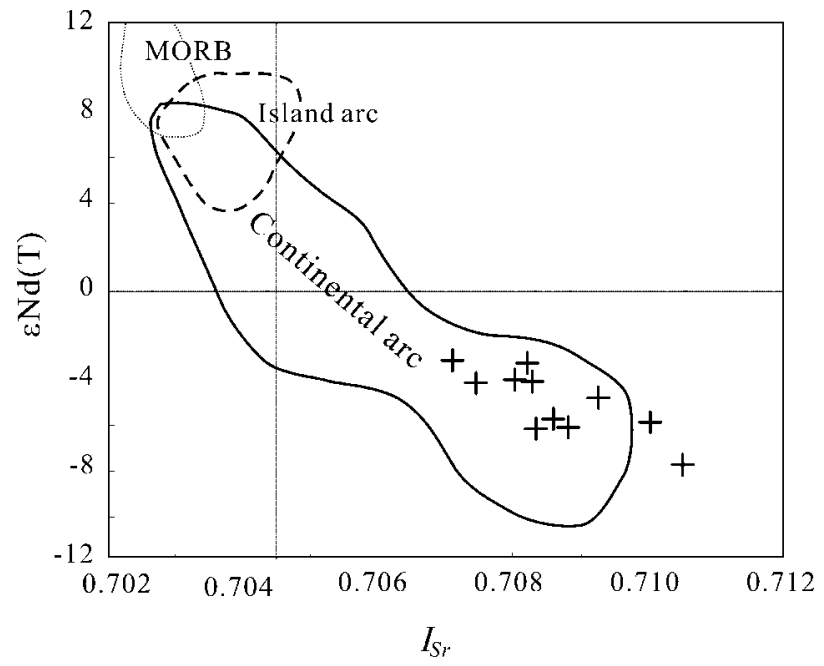

Figure 9. Plot of $\varepsilon \mathrm{Nd}(T)$ versus $I_{\mathrm{Sr}}$ for the Wuzhishan Orthogneiss. Sr-Nd isotopic composition ranges for midocean ridge basalts (MORB), island arc basalts, and continental arc basalts are from compilation of Tatsumi and Eggins (1995). 

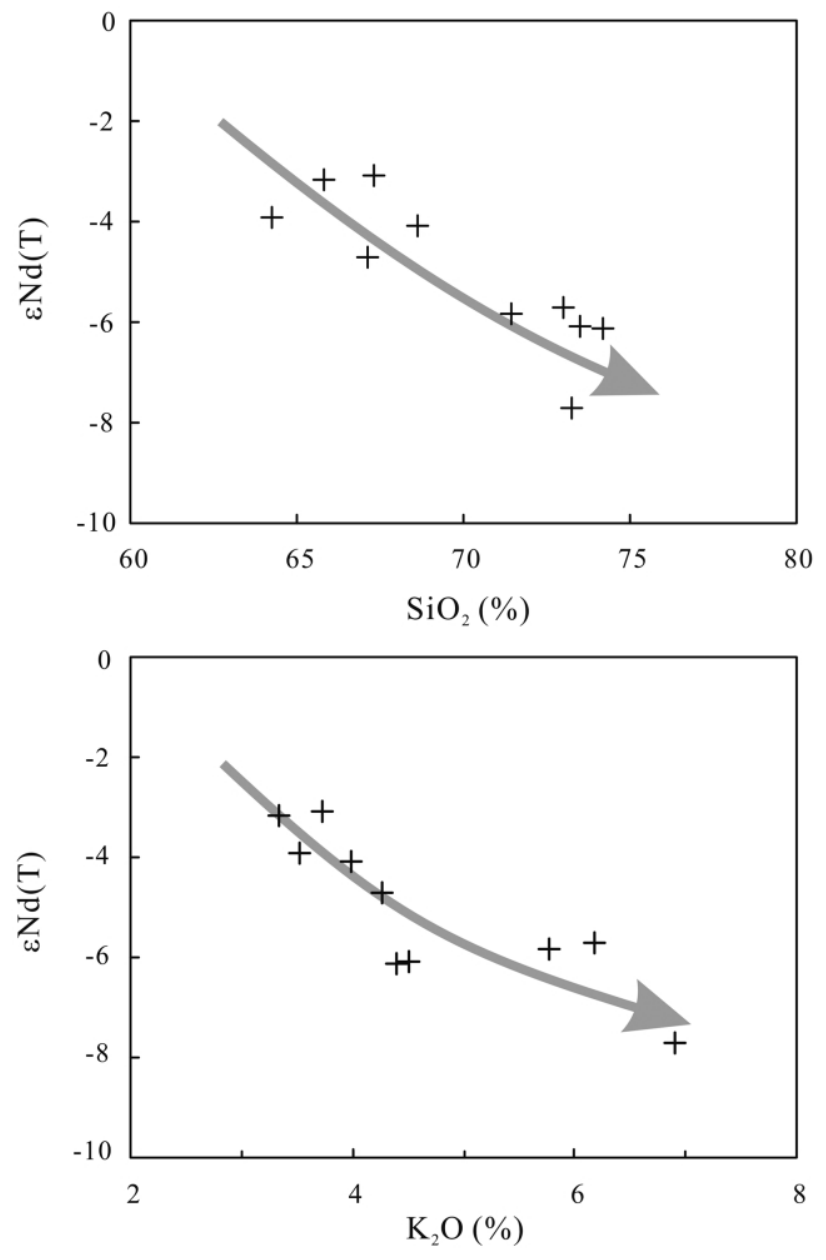

Figure 10. Plot of $\varepsilon \mathrm{Nd}(T)$ versus $\mathrm{SiO}_{2}$ and $\mathrm{K}_{2} \mathrm{O}$.

trends in Hainan Island seem to be different from those in northern Vietnam (Lepvrier et al. 2004). However, it is unclear whether they are genetically related.

It has been commonly accepted that a continental magmatic arc existed along the southeastern coast of South China (e.g., Jahn et al. 1990; Zhou and Li 2000), but it is unclear exactly when the arc was initiated. In view of the lack of widespread arc volcanism in the early Mesozoic along the coastal region, it was suggested that the arc system was probably not initiated until around mid-Jurassic, when the final suturing between the North and South China blocks slowed down the northward movement of the South China Block (Li 1998). Our work here for the first time demonstrates that the arc system probably started as early as the late Lower Permian time (fig. 11). The Late Permian to earliest Triassic metamorphism was reported in Taiwan (260-240 Ma; Yuan et al. 1985; Jahn et al. 1992). Farther inland, currently on the other side of the Taiwan Strait, the contemporaneous 252-242 Ma syenites were recently identified in northwestern Fujian (Wang et al. 2005). These syenites are typical ultrapotassic to potassic rocks characterized by strong enrichment in large-ion lithophile elements and LREEs and depletion in high-fieldstrength elements, strikingly similar to those of high-K/Ti and low-Ti potassic magmas formed in subduction-related settings (Rogers 1992). We consider the contemporaneous metamorphism and ultrapotassic magmatism evidence of the possible existence of a northeastern extension of that arc system (fig. 11b).

The presence of a continental arc off the present southeastern coast of South China is also consistent with the sudden change in the sedimentary environment in the Permian time. As shown in figure $11 a$, South China was almost entirely covered by platformal carbonate during the Carboniferous to earliest Permian time (Liu and Xu 1994). It is thus most likely that a passive margin was off its southeastern coast (present coordinates; fig. 11a). However, such a low-energy sedimentary environment suddenly ceased during late Early Permian (ca. $270 \mathrm{Ma}$; fig. 11b), when an elongated uplift developed along the southeastern coast and clastic sediments were shed from this uplift into an inland basin, a possible foreland basin (Li 1998). This event coincides with the timing of arc magmatism on Hainan Island reported in this study and may indicate the initiation of the continental arc system (fig. 11b). This active continental margin in South China was likely triggered by the onset of the North China-South China continental collision at late Early Permian (ca. $270 \mathrm{Ma}$; Zhao and Coe 1987), which retarded the rate of northward drift of the South China Block.

\section{Conclusions}

SHRIMP U-Pb zircon analysis suggests that the Wuzhishan granites were crystallized at 267-262 $\mathrm{Ma}$. They show close geochemical and Sr-Nd isotopic affinities to the calc-alkaline I-type granites formed in continental arc, suggesting an active continental margin off the present southeastern coast of South China in late Early Permian time. This emerging orogeny, i.e., the South China Indosinian Orogeny, resulted from the oceanic subduction during the late Early Permian and uplifted the coastal region and shed terrestrial sediments to the inland. 

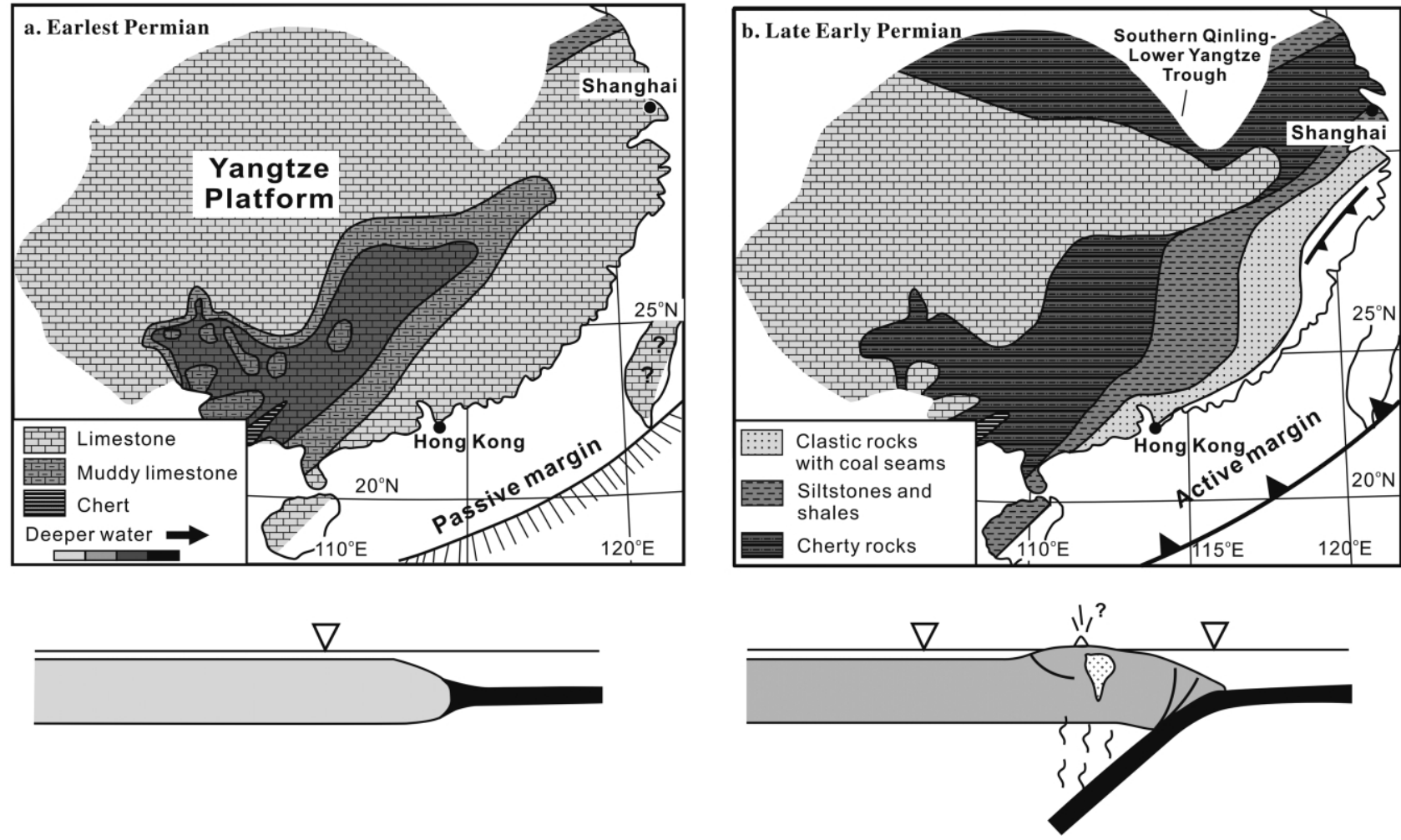

Figure 11. Simplified basin geometry of South China during the Permian time (after Liu and Xu 1994; Li 1998) and the interpreted initiation of a continental arc system along its southeastern coast.

\section{A C K N O W L E D G M E N T S}

We thank S. J. Ding, H. W. Zhou, and X. Y. Ge for assistance in fieldwork, B. Song and $\mathrm{H}$. Tao for help with zircon dating, and Y. Liu, X. L. Tu, and X. R. Liang for geochemical and isotopic analyses. Com- ments by L. Webb and an anonymous reviewer improved the manuscript. This work was supported by the National Science Foundation of China (grants 40334039 and 40421303) and the Chinese Academy of Sciences (grants KZCX2-102 and 20032-1).

\section{R E F E R E N C E S C I T E D}

Barker, F., and Arth, J. G. 1976. Generation of trondhjemitic-tonalitic liquids and Archean bimodal trondhjemite-basalt suites. Geology 4:596-600.

Barth, A. P.; Wooden, J. L.; Tosdal, R. M.; and Morrison, J. 1995. Crustal contamination in the petrogenesis of a calc-alkalic rock series: Josephine Mountain intrusion, California. Geol. Soc. Am. Bull. 107:201-212.

Black, L. P.; Kamo, S. L.; Allen, C. M.; Aleinikoff, J. N.; Davis, D. W.; Korsch, R. J.; and Foudoulis, C. 2003. TEMORA 1: a new zircon standard for Phanerozoic U-Pb geochronology. Chem. Geol. 200:155-170.

Carter, A.; Roques, D.; Bristow, C.; and Kinny, P. 2001. Understanding Mesozoic accretion in Southeast Asia: significance of Triassic thermotectonism (Indosinian orogeny) in Vietnam. Geology 29:211-214.
Chappell, B. W. 1999. Aluminium saturation in I- and Stype granites and the characterization of fractionated haplogranites. Lithos 46:535-551.

Chen, A. 1999. Mirror-image thrusting in the South China Orogenic Belt: tectonic evidence from western Fujian, southeastern China. Tectonophysics 305:497519.

Chen, J. F.; Foland, K. A.; Xing, F.; Xu, X.; and Zhou, T. X. 1991. Magmatism along the southeast margin of the Yangtze block: Precambrian collision of the Yangtze and Cathaysia blocks of China. Geology 19:815-818.

Chen, S. F., and Wilson, C. J. L. 1996. Emplacement of the Longmen Shan Thrust-Nappe Belt along the eastern margin of the Tibetan Plateau. J. Struct. Geol. 18: 413-440. 
Cui, S. Q., and Li, J. R. 1983. On the Indosinian orogeny along the western Pacific coast areas of China. Acta Geol. Sin. 62:51-61 (in Chinese).

Cumming, G. L., and Richards, J. R. 1975. Ore lead isotope ratios in a continuously changing Earth. Earth Planet. Sci. Lett. 28:155-171.

Defant, M. J.; Jackson, T. E.; Drummond, M. S.; De Boer, J. Z.; Bellon, H.; Feigenson, M. D.; Maury, R. C.; and Stewart, R. H. 1992. The geochemistry of young volcanism throughout western Panama and southeastern Costa Rica: a review. J. Geol. Soc. Lond. 149:569-579.

Deprat, J. 1914. Les charriages de la region de la Rivière Noire sur les feuilles de Thanh-ba et Van-Yên. Mém. Serv. Géol. Indochine 2:27-65.

Hacker, B. R.; Ratschbacher, L.; Webb, L.; Ireland, T.; Walker, D.; and Dong, S. W. 1998. U/Pb zircon ages constrain the architecture of the ultrahigh-pressure Qinling-Dabie orogen, China. Earth Planet. Sci. Lett. 161:215-230.

Harrowfield, M. J., and Wilson, C. J. L. 2005. Indosinian deformation of the Songpan Garze Fold Belt, northeast Tibetan Plateau. J. Struct. Geol. 27:101-117.

Hickey-Vargas, R.; Moreno Roa, H.; Lopez Escobar, L.; and Frey, F. A. 1989. Geochemical variations in Andean basaltic and silicic lavas from the VillarricaLanin volcanic chain $\left(39.5^{\circ} \mathrm{S}\right)$ : an evaluation of source heterogeneity, fractional crystallization and crustal assimilation. Contrib. Mineral. Petrol. 103:361-386.

Hsü, K. J.; Sun, S.; Li, J. L.; Chen, H. H.; Pen, H. P.; and Sengor, A. M. C. 1988. Mesozoic overthrust tectonics in south China. Geology 16:418-421.

Jahn, B. M.; Chi, W. R.; and Yui, T. F. 1992. A late Permian formation of Taiwan (marbles from Chia-Li Well No. 1): $\mathrm{Pb}-\mathrm{Pb}$ isochron and $\mathrm{Sr}$ isotopic evidence, and its regional geological significance. J. Geol. Soc. China 35:193-218.

Jahn, B. M.; Wu, F. Y.; Capdevila, R.; Martineau, F.; Zhao, Z. H.; and Wang, Y. X. 2001. Highly evolved juvenile granites with tetrad REE patterns: the Woduhe and Baerzhe granites from the Great Xing'an Mountains in NE China. Lithos 59:171-198.

Jahn, B. M.; Zhou, X. H.; and Li, J. L. 1990. Formation and tectonic evolution of southeastern China and Taiwan: isotopic and geochemical constraints. Tectonophysics 183:145-160.

Keto, L. S., and Jacobsen, S. B. 1987. Nd and Sr isotopic variations of Early Paleozoic oceans. Earth Planet. Sci. Lett. 84:27-41.

Lacassin, R.; Leloup, P. H.; Trinh, P. T.; and Tapponnier, P. 1998. Unconformity of red sandstones in north Vietnam: field evidence for Indosinian orogeny in northern Indochina? Terra Nova 10:106-111.

Lepvrier, C.; Maluski, H.; Nguyen, V. V.; Roques, D.; Axente, V.; and Rangin, C. 1997. Indosinian NW-trending shear zones within the Truong Son belt (Vietnam) ${ }^{40} \mathrm{Ar} /{ }^{39} \mathrm{Ar}$ Triassic ages and Cretaceous to Cenozoic overprints. Tectonophysics 283:105-127.

Lepvrier, C.; Maluski, H.; Vu, V. T.; Leyreloup, A.; Phan, T. T.; and Nguyen, V. V. 2004. The Early Triassic Indosinian orogeny in Vietnam (Truong Son Belt and
Kontum Massif): implications for the geodynamic evolution of Indochina. Tectonophysics 393:87-118.

Li, S. G.; Xiao, Y. L.; Liou, D. L.; Chen, Y. Z.; Ge, N. J.; Zhang, Z. Q.; Sun, S. S.; et al. 1993. Collision of the North China and Yangtse blocks and formation of coesite-bearing eclogites: timing and processes. Chem. Geol. 109:89-111.

Li, X. H. 1997. Geochemistry of the Longsheng Ophiolite from the southern margin of Yangtze Craton, SE China. Geochem. J. 31:323-337.

Li, X. H.; Liu, D. Y.; Sun, M.; Li, W. X.; Liang, X. R.; and Liu, Y. 2004. Precise Sm-Nd and U-Pb isotopic dating of the super-giant Shizhuyuan polymetallic deposit and its host granite, southeast China. Geol. Mag. 141: 225-231.

Li, X. H., and McCulloch, M. T. 1996. Secular variations in the $\mathrm{Nd}$ isotopic composition of Late Proterozoic sediments from the southern margin of the Yangtze Block: evidence for a Proterozoic continental collision in SE China. Precambrian Res. 76:67-76.

Li, X. H.; Zhou, H.; Chung, S. L.; Ding, S.; Liu, Y.; Lee, C. Y.; Ge, W.; Zhang, Y.; and Zhang, R. 2002a. Geochemical and Sm-Nd isotopic characteristics of metabasites from central Hainan Island, South China and their tectonic significance. Island Arc 11:193-205.

Li, Z. X. 1998. Tectonic history of the major East Asian lithospheric blocks since the mid-Proterozoic: a synthesis. In Flower, M. J.; Chung, S. L.; Lo, C. H.; and Lee, T. Y., eds. Mantle dynamics and plate interactions in East Asia. AGU Geodynamics Ser. 27:221-243.

Li, Z. X.; Li, X. H.; Zhou, H.; and Kinny, P. D. $2002 b$. Grenville-aged continental collision in South China: new SHRIMP U-Pb zircon results and implications for Rodinia configuration. Geology 30:163-166.

Liu, B., and Xu, X. 1994. Atlas of lithofacies and paleogeography of South China. Beijing, Science Press, 188 p.

Maniar, P. D., and Piccoli, P. M. 1989. Tectonic discrimination of granitoids. Geol. Soc. Am. Bull. 101:635643.

Meng, Q. R., and Zhang, G. W. 2000. Geologic framework and tectonic evolution of Qinling orogen, central China. Tectonophysics 323:183-196.

Metcalfe, I. 1996. Gondwanaland dispersion, Asian accretion and evolution of eastern Tethys. Aust. J. Earth Sci. 43:605-623.

Rapp, R. P., and Watson, E. B. 1995. Dehydration melting of metabasalt at 8-32 kbar: implications for continental growth and crust-mantle recycling. J. Petrol. 36: 891-931.

Rodgers, J. 1989. Comment on "Mesozoic overthrust tectonics in south China." Geology 17:671-672.

Roger, F.; Malavieille, J.; Leloup, P. H.; Calassouc, S.; and $\mathrm{Xu}, \mathrm{Z}$. 2004. Timing of granite emplacement and cooling in the Songpan-Garzê Fold Belt (eastern Tibetan Plateau) with tectonic implications. J. Asian Earth Sci. 22:465-481.

Rogers, N. W. 1992. Potassic magmatism as a key to trace-element enrichment processes in the upper mantle. J. Volcanol. Geotherm. Res. 50:85-99. 
Rowley, D. B.; Ziegler, A. M.; and Gyou, N. 1989. Comment on "Mesozoic overthrust tectonics in south China." Geology 17:384-386.

Rushmer, T. 1991. Partial melting of two amphibolites: contrasting experimental results under fluid-absent conditions. Contrib. Mineral. Petrol. 107:41-59.

Sisson, T. W.; Ratajeski, K.; Hankins, W. B.; and Glazner, A. F. 2005. Voluminous granitic magmas from common basaltic sources. Contrib. Mineral. Petrol. 148: 635-661.

Sun, S. S., and McDonough, W. F. 1989. Chemical and isotopic systematics of oceanic basalt: implications for mantle composition and processes. In Saunders, A. D. and Norry, M. J., eds. Magmatism in the ocean basins. Geol. Soc. Spec. Publ. 42:528-548.

Tatsumi, Y., and Eggins, S. M. 1995. Subduction zone magmatism. Cambridge, MA, Blackwell Science, 211 p.

Wang, Q.; Li, J. W.; Jian, P.; Zhao, Z. H.; Xiong, X. L.; Bao, Z. W.; Xu, J. F.; Li, C. F.; and Ma, J. L. 2005. Alkaline syenites in eastern Cathaysia (South China): link to Permian-Triassic transtension. Earth Planet. Sci. Lett. 230:339-354.

Wang, X. F.; Ma, D. Q.; and Jiang, D. H. 1991. Geology of Hainan Island (II): Magmatic rocks. Beijing, Geological Publishing House, 274 p. (in Chinese).

Wei, G. J.; Liang, X. R.; Li, X. H.; and Liu, Y. 2002. Precise measurement of Sr isotopic compositions of liquid and solid base using (LP) MC-ICP-MS. Geochimica 31: 295-305 (in Chinese with English abstract).

Whalen, J. B.; Currie, K. L.; and Chappell, B. W. 1987. Atype granites: geochemical characteristics, discrimination and petrogenesis. Contrib. Mineral. Petrol. 95: 407-419.

Williams, I. S. 1998. U-Th-Pb geochronology by ion microprobe. In Applications of microanalytical techniques to understanding mineralizing processes. Rev. Econ. Geol. 7:1-35.

Yan, D. P.; Zhou, M. F.; Song, H. L.; Wang, X. W.; and Malpas, J. 2003. Origin and tectonic significance of a Mesozoic multi-layer over-thrust system within the Yangtze Block (South China). Tectonophysics 361: 239-254.

Yuan, J. W.; Lin, S. J.; Huang, S. T.; and Show, C. L. 1985. Stratigraphic study on the pre-Miocene under the Peikang area, Taiwan. Petrol. Geol. Taiwan 21:115-127.

Zhao, X., and Coe, R. S. 1987. Palaeomagnetic constraints on the collision and rotation of North and South China. Nature 327:141-144.

Zhou, X. M., and Li, W. X. 2000. Origin of Late Mesozoic igneous rocks in southeastern China: implications for lithosphere subduction and underplating of mafic magmas. Tectonophysics 326:269-287. 